\title{
A honeybee-mating approach for cluster analysis
}

\author{
Mohammad Fathian • Babak Amiri • Ali Maroosi
}

Published online: 25 October 2008

(C) Springer-Verlag London Limited 2008

Erratum to: Int J Adv Manuf Technol (2008) 38:809-821

DOI 10.1007/s00170-007-1132-7

Unfortunately, one of the author was omitted in the original article.

The correct information is given below.

Mohammad Fathian, Babak Amiri, Ali Maroosi

The online version of the original article can be found at http://dx.doi. org/10.1007/s00170-007-1132-7.

M. Fathian $\cdot$ B. Amiri $(\varangle) \cdot$ A. Maroosi

Department of Industrial Engineering,

Iran University of Science and Technology,

Narmak,

Tehran 123456, Islamic Republic of Iran

e-mail: amiri_babak@ind.iust.ac.ir 